\title{
Managing religions: state responses to religious diversity
}

\author{
Bryan S. Turner
}

Published online: 23 June 2007

(C) Springer Science + Business Media B.V. 2007

\begin{abstract}
After 9/11 there is a general sense of the crisis of liberalism and secularism, and the need for greater security and surveillance. Diasporic Muslim communities have been increasingly the target of government interventions and investigations, resulting in various forms of governmentality that in fact constitute a 'management of Muslims.' The traditional strategies of benign neglect have been replaced by periods of intense governmental activity. The idea of 'managing Muslims' is often disguised by a more neutral terminology such as pluralism or multiculturalism. This article examines two versions of the management of religions from policies of 'upgrading' or retraining of Muslims for modernity to more robust policies of containment, rendition and seclusion. The result of securitisation and globalisation is the rise of a new type of society that I call 'the enclave society.' In such societies governments are creating new policies of 'enclavement' to quarantine communities that are undesirable or unwanted or dangerous. The mobility of a global society is now being constrained by encirclement and enclavement through building walls, ghettoes, catchments and no-go areas. Such policies are likely to be counter productive, requiring an escalation of draconian interventions.
\end{abstract}

Keywords Enclave(ment) · Exclusion · Governmentality · Liberalism · Multiculturalism

\section{Introduction}

Because international migration inevitably creates greater religious diversity through the development of diasporic communities, contemporary social diversity is in large measure the unintended consequence of the globalisation of the labour market. The

B. S. Turner $(\bowtie)$

Asia Research Institute, National University of Singapore, A5 Arts Links,

Level 4 AS7 Shaw Foundation Building, Singapore 117570, Singapore

e-mail: aribst@nus.edu.sg 
complex legal and political issues surrounding religious tolerance and conflict have therefore been produced by economic globalisation in the second half of the twentieth century. Religious diversity has, with the collapse of communism and the rise of fundamentalism, become a major political issue in democratic societies, because we do not, in general terms, possess robust social policies and institutions to manage the social tensions that flow from cultural complexity and the conventional liberal solutions, especially the legacy of the Treaty of Westphalia of 1648 which is the foundation of modern liberal policies in the West, are in a state of crisis (Turner 2006a). In this article I consider the increasingly difficult problems of multiculturalism and religious diversity in relation to the state and the law, especially after the international crisis created by the terrorist acts of $9 / 11$, and the bombings in Bali, London and Madrid. The states of the advanced societies can no longer rely on the conventional division between politics and religion, and have entered into a new phase that involves the direct management of religions. Liberal states have evolved from policies of benign neglect to active management of religious activities. In practice, these new strategies are primarily concerned with managing Muslims under the banner of pluralism and multiculturalism. These developments can be understood in terms of Michel Foucault's concept of governmentality, since managing religions is a recent adjunct of the more general functions of the administrative state (Foucault 2000). Managing religions is important, if the state is to re-assert its authority over civil society, especially over those religious institutions that seek to articulate an alternative vision of power and truth, and if it is to command the loyalty of its citizens over and above other claims of membership.

In this argument, I distinguish two forms of management of religions or governmentality of religions. The first is the liberal model and its variants that constitute what I shall call a strategy of upgrading religions. With respect to Islam, these policies tend to assume that Islam has to be modernised if it is to be compatible with liberal democratic regimes. This is in fact the policy of creating so-called 'moderate Muslims.' The strategies that are involved here include educational policies to raise the educational level of Muslim communities, including providing educational improvement of Muslim leaders, especially the mullahs. It is also involves providing legislation to give Muslim women security, opportunities in education, and encouragement to enter the open marriage market, thereby rejecting arranged marriages. It may also involve inducements to abandon the veil or other forms of modesty and seclusion. Finally these forms of government also involve opposition to what are seen to be brutal criminal law decisions, such as amputation. In short, liberal management of religion is intended to modernise Islam through a set of procedures that bring about a partial secularisation of Islam. Although the majority of Muslims would regard these strategies as deeply problematic because they appear to change the nature of personal piety, a small group of modernists might themselves welcome such strategies. These liberal policies may well be compatible for example with the modernising thought of Abdolkarim Soroush (Sadri and Sadri 2000).

If liberal management through upgrading Islam is a conscious and explicit policy, for example in the religious policies of the secular government of Singapore, the more repressive strategy of containment through the creation of enclaves is often the unintended consequence of earlier attitudes of neglect or indifference. In a criticism of much contemporary globalisation theory, I argue that modern society is 
becoming an enclave society in which various practices including the creation of ghettoes and no-go areas produce strategies of cultural quarantine. In these strategies, migrant minority communities do not enjoy modern mobilities but became a fixed underclass without the normal range of rights available to full citizens. If the first strategy is one of upgrading, the second is a strategy of what I shall call 'enclavement.' The word 'enclave' comes from the Latin for key (clavis) and therefore to enclave a community is to lock it up, but the modern enclave is not simply a walled society; there are many new technologies available to governments whereby they can exercise surveillance and control without obvious physical barriers. We might speculate that enclavement is a strategy that is adopted when upgrading policies appear to have already failed or for political reasons are made to fail. After 9/11 enclavement has become the dominant paradigm as liberal upgrading policies are subject to political criticism. The ultimate illustration of modern enclavement is indeed Guantanamo Bay, an area of extra-legal containment and rendition.

Diversity and hybridity, are the unintended consequences of the social fluidity of a globalised world. The capitalist labour markets of advanced economies depend on high levels of international migration, both legal and illegal, because they have certain demographics characteristics that may bring about economic stagnation: ageing populations and low fertility. In addition, the labour force of the advanced economies is either insufficiently mobile or reluctant to take on unskilled or low-paid work. While global labour markets need migrants, democratic governments, often responding to electoral pressures and racist media campaigns, cannot appear to be too lenient towards uncontrolled migration, especially towards asylum seekers and refugees. Indeed after 9/ 11 , there has been an unfortunate tendency in democratic parliaments to conflate three otherwise distinct categories of mobile persons: migrants, refugees and asylum seekers. Conservative or right-wing governments have successfully mobilised electorates against liberal policies towards labour mobility, porous frontiers and the expansion of the European Union, but even the social democratic countries of Scandinavia and northern Europe have faced acute political difficulties over migration as we have seen in Denmark, Sweden and The Netherlands. While migrants contribute significantly to economic growth and in the long term to population growth, they are often thought to be parasitic upon the host society. They do not fit easily into a welfare model of citizenship and contributory rights, in which future benefits depend on past and present contributions to society through public service, reproduction and payment of taxes.

Providing citizenship to migrants may be one step towards reducing the likelihood of civil conflict. However, governments have often been reluctant to give citizenship status to migrants without stringent criteria of membership and naturalisation is often a slow and complex process. Some political groups on the right hanker after repatriation rather than naturalisation. The United States, Britain and The Netherlands have been discussing the desirability of increasing the difficulty and scale of the tests relating to history, law and language which migrants might be expected to take as a preparation for full citizenship. While dual citizenship continues to be regarded as a legal anomaly, there is as a result ongoing social criticism directed against quasi-citizenship, dual citizenship and other flexible arrangements. These forms of political membership and association are assumed to undermine the hegemonic model of traditional political identity and they ultimately contradict many of the traditional assumptions behind national sovereignty. 


\section{The liberal vision of consensus}

Given the global development of religious revivalism and religious nationalism, new political questions have emerged about how states can best manage pluralism, religious diversity and ethnic divisions. The classic liberal solution has been presented by Rawls (1999) in his The Laws of People where he argues that what he calls a "decent liberal society" will require "an overlapping consensus" in which social order must be rooted in a reasonable political conception of right and where political harmony is affirmed by an overlapping consensus of comprehensive doctrines. In attempting to provide the classical liberal defence of freedom of speech and conscience, Rawls struggles with the traditional liberal problem that some religious fundamentalists or political groups may not accept the liberal version of a plural society. How does a liberal respond to somebody or group which simply rejects liberalism? Rawls provides no real practical solution to this conventional conundrum. In historical terms in response to the carnage of religious conflict in the seventeenth century, liberalism solved religious conflict by making religion a matter of private belief, and separating church and state. These political solutions were initially enshrined in John Locke's 'Letter on tolerance' which was composed in 1667 and in The Second Treatise of Government in 1690 (Locke 1946). Locke's principles of government - government by consent, the responsibility of government for the welfare of the community, the church as voluntary association, and the limitation of the power of magistrates - became the backbone of liberalism for at least a century. Perhaps the limitation of Locke's individualism is that he did not recognise the binding power of social ties, especially of race and nationalism.

In contemporary liberalism, Rawls's solutions to ethnic diversity are essentially legal and political: rule of law, norms of compromise, reasonableness, and the protection of individual rights. Rawls argues that a decent liberal society will require an overlapping consensus of beliefs if it is to avoid social disharmony. In particular, Rawls (1999:16) suggests that ' $[\mathrm{b}] \mathrm{ecause}$, philosophical or moral unity is neither possible nor necessary for social unity, if social stability is not merely a modus vivendi, it must be rooted in a reasonable political conception of right and justice affirmed by an overlapping consensus of comprehensive doctrines.' Rawls is of course acutely aware that his liberal model is problematic in the face of powerful exclusionary "comprehensive doctrines" such as those emerging from the belief systems of evangelical movements or fundamentalism. He admits that "differences between citizens arising from their comprehensive doctrines" may turn out to be "irreconcilable." His solution is to propose a criterion of "reasonableness" or reciprocity in which citizens are "prepared to offer one another fair terms of cooperation of political justice" and according to which they will accept each other even at the cost of their own interests. He defines this criterion of reciprocity by appeal to a classical notion of Greek political philosophy namely 'civic friendship.' Because "friendship" has in modern discourse lost its political, if not its ethical, significance, Rawls's argument might be lost on a modern audience. In classical Greece, friendship (philotes/philia) designated a set of obligations, on the part of the head of a household (oiko-despotes) towards strangers involving mutual respect. In the Nichomachean Ethics, Aristotle claimed that friendship was a universal emotion forming the basis of the polis, because the citizen was always the fellow-citizen of civil society. 
Rawls's ideas are valuable. Indeed it is difficult to see how civil society could function without the rule of law, tolerance and mutual respect. Civil society needs the social solidarity that is associated with such fellow feeling. These ideas may be praiseworthy, but are they realistic and does merely the promise of reciprocity solve the problem of mutually exclusive belief systems? On the basis of changes in the nature of everyday norms and customs in religiously plural societies, Rawls's criteria for "a realistic utopia" that is for "reasonably just constitutional democratic societies" look unpromising. These liberal criteria of functional democracies are seriously challenged by contemporary religious movements. The principal weakness of Rawls's argument is sociological that is, a consensus of overlapping comprehensive doctrines can only provide the basis for a workable consensus in civil society if there are overlapping social bonds. A multicultural society with diverse comprehensive doctrines - the product of diverse fundamentalist religions - can only function with minimal social conflict if there are overlapping social groups. The existence of overlapping social groups is only possible where there are high rates of inter-marriage, state schools catering to ethnically distinct communities, sports teams that recruit from various ethnic groups, neighbourhoods that are not zoned by separate housing arrangements, restaurants serving a variety cuisines, and government policies that promote multicultural participation across the whole of society. Such overlapping social bonds are not being easily sustained because the consequence of the growth in personal piety that is associated with the development of fundamentalist belief is the creation of a social mosaic of separate and sequestered communities.

From a sociological perspective, an overlapping consensus of comprehensive doctrines presupposes the existence of overlapping social groups. However, inter-group reciprocity and co-operation often appear to be in decline in modern societies. In addition, the actual debate about cultural co-operation and consensus has been undercut by the long standing and intractable problem of cultural relativism. Recent political philosophy has sought to develop notions of cosmopolitanism that might counter-act this slide towards the celebration of cultural distinctiveness. While liberal multiculturalists have embraced recognition theory as an ethical platform for inter-cultural cooperation and mutual respect, such a position does not pay sufficient attention to the actual existence of widespread disagreements over values. What happens in multicultural societies where people simply disagree about basic issues to such a degree that no overlapping consensus is possible? One response is to seek out elements in other cultures where the prospects for recognition and agreement are promising, and hence such a response keeps open the possibility of dialogue even where there are large areas of disagreement. If there is to be a dialogue between western secular liberals and religious leaders outside the west, we need some common ground.

\section{Contestation and the public sphere}

In order to understand the implications of religious pluralism and the expanding governmental art of the management of religions, we need to understand the major changes taking place in society, state and economy over the last four decades. In particular, we need to appreciate how changes in civil society, the role of social classes and employment are affecting the public sphere of debate and contestation. I 
propose that we cannot understand the management of religion without understanding the management of capitalism. In The New Spirit of Capitalism Boltanski and Chiapello (2005) provide a summary of the major changes in the social structure of modern capitalism - in terms of class formation, the role of the state, the character of industrial relations and the rise and fall of ideologies - since the 1960s. They attempt to produce a revision of Max Weber's concept of 'spirit of capitalism' by analyzing the discourses by which the social order is legitimated and individuals are motivated to engage in tasks and occupations. Their work is also an attempt to demonstrate the centrality of human agency in explanations of historical change, and finally it represents an attempt to (re)create a critical and moral sociology that will explore the issues of justice and inequality in modern societies. If one were to summarise these objectives, it is to say that the book is an attempt to write a general but critical theory of modernity.

In order to understand these changes in the modern world, Boltanski and his colleagues have invented a new vocabulary to describe the contested nature of public life. This new vocabulary is set in the context of the view that critical social science especially critical theory inspired by Marxism - has been in decline since May 1968. Boltanski, Thevenot, Chiapello and others seek to reinvent a post-Marxist critical theory in which a sociological critique engages with the great variety of public debates which also challenge social institutions, and which as a result demand some justification of power. This approach means that sociologists need to take seriously what social actors themselves have to say about society and to pay attention to how their agency is manifest in social change. For example Boltanski and Chiapello are particularly interested in the role of indignation in social movements. They say this 'indignation emerges in historically situated forms, while doubtless being rooted in anthropologies that possess very general validity. Forms of indignation may be regarded as emotional expressions of a meta-ethical anchorage, and concern infringements that are believed, at least implicitly, to affect people's possibilities of realizing their humanity' (p. 491). Boltanski and Chiapello want a sociology of action and justification in which agency is given its full recognition and in which actors are knowledgeable and capable of bringing about change through protest, action and debate. Their emphasis on agency and justice leads them to characterise the public order in terms of confrontations between different orders of belief and value. This analysis of the public sphere attempts to steer a course between conceptualising society as an endless arena of violence, power and confrontation (Nietzsche, Marx, Foucault and Bourdieu) and between a contractual vision of social consensus (Rawls, Habermas and the communitarians). Boltanski and Chiapello are clear that they wish to avoid the idea that justification is merely ideological superstructure, since, for them, justification also exerts constraints on capitalism that limits the impact of alienation and exploitation. Boltanksi shares with Jurgen Habermas a recognition of the importance of social norms in both constraining and justifying social action, but they do not assume that actual capitalist societies are built on a value consensus. On the contrary, they perceive the public sphere as one of endless debate between different orders of value. Concentrating on disagreements in society, they develop the idea of six logics of justification that they call 'cities' or political communities, namely the inspirational city, the domestic city, the reputational city, the civic city, the commercial city and the industrial city (pp. 23-24). To this list, they add their own interpretation of 型 Springer 
the modern political community, namely the network city. Each city has been the topic of classical political and social theory and thus for example Rousseau was the philosopher of the civic city and Saint-Simon of the industrial city. Each city needs to find a balance between the notion of a common humanity and the existence of pluralistic values and interests. This superior principle of humanity provides a hierarchy of values involving an order of greatness (grandeur). The order of greatness in the inspirational city was sanctity, in the industrial city it was inventiveness and expertise. Disputes between values result in the creation of tests which are intended to settle disputes. These tests often fail, because there is in fact no agreement on a common principle and people in the network city can always appeal to other earlier cities - such as sanctity as a principle of conflict resolution.

From a conventional sociological perspective, one of the more interesting aspects of their work is the notion that social exclusion has replaced social class as the principle of social differentiation and division. Exclusion, unlike social class membership, is projected as somebody's fault and handicap is now essentially a social attribute. Exclusion is now seen to be a matter of natural talents which some people develop and others do not. In what they call 'the connexionist world,' successful people are incessantly on the move, while the unsuccessful that are seen to have squandered their talents are characterised by their social and spatial fixity. Whereas exploitation in a class society could be tested in terms of its profitability (for example in the labour theory of value), it is unclear how mobility in a network society can be tested in terms of its actual contributions to capitalism. How can mobility as such find its justification?

The New Spirit of Capitalism is a powerful and comprehensive account of modern society that develops an impressive critique of modern patterns of exclusion. It is an important counterweight to Rawls, since they do not presuppose that a value consensus is a consequence of debate and contest, recognising instead that within the network city agreements may be fragile and precarious. They also have a clear understanding of the role of indignation in major disagreements about values. Conflicts over religious tolerance, pluralism and religious diversity are important illustrations of the role of value confrontation within the modern public sphere. In its original formulation, multiculturalism held out the promise of both the celebration of cultural difference and the possibility of social harmony based upon mutual trust, respect and recognition, but there is a general crisis surrounding multiculturalism. Many western governments appear to be retreating from multicultural policies, stressing assimilation, naturalisation and securitization.

In modern Europe, multiculturalism has become a code word for 'the management of religious diversity' and coping with religious diversity in fact means 'the management of Muslims.' France of course could be said to be at the coal-face of the problem, given the state's problematic response to the 'head-scarf affair.' Critical sociology and Marxism were in retrospect notorious for the neglect of religion, which was seen as either an ideology of pre-capitalist societies or a superstition that would, in the face of scientific systems of knowledge, wither away. Religion has however returned to the centre of political debate. One might argue that one problem with religious fundamentalism (in Judaism, Christianity and Islam) is that it wants to draw its values from the inspirational cities of Jerusalem and Mecca rather than from Athens and Rome, from the holy city rather than from network society, and hence it is difficult to resolve value disputes in 
modern society by a test that could be mutually acceptable. Therefore, civil society remains unstable. The debate is especially acute in France given the legacy of republican secularism and the cultural dominance of the Catholic Church against the alternative voices of reformist Islam which owes more to Sayyid Qutb and Ayatollah Ruhollah Khomeini than to Rousseau and Condorcet. Although a conceptual analysis of capitalism does not require any reference to Islam, any discussion of regimes of justification in France can hardly avoid it. Any study of indignation and justice must address the social movements that have coalesced around women, domesticity and the labour market, or around ethnicity, exclusion and housing or around religion, dignity and national values? France has been virtually the European social laboratory for such contestations, the space within which upgrading and enclavement have found a management role.

Much of the negative view of cultural diversity and dialogue has been shaped by Huntington's (1993) article on 'the clash of civilizations' in Foreign Affairs. In the post 9/11 world, Huntington's bleak analysis of the development of micro fault-line conflicts and macro core state conflicts has influenced the interventionist assumptions of western foreign policy in the era of the 'war on terror.' Huntington of course believes that the major division of civilisations is between the Christian West and the Muslim world, and he claims that in the age of Muslim Wars America has to deal with widespread Muslim grievance and hostility. Although the Huntington's thesis might be seen as an extreme position, what seems to be beyond question is that religious complexity resulting from both legal and illegal migration poses new challenges for the state, because religious complexity creates new burdens on democratic political structures, and it is a major test of the institutions of social citizenship. Cultural and social diversity, including a trend towards legal pluralism, requires a vigorous defence of the rule of law if societies are to avoid social conflict. There are many possible strategies for the management of ethnic diversity, but passive tolerance of migrants and arbitrary exclusion of asylum seekers does not constitute an effective political option.

The emergence of ethnic enclaves is a typical development of colonial states, whitesettler communities and migrant societies. The indigenous populations of the United States, Australia and South Africa are typical examples of such forms of governmentality. Political scientists are also familiar with the complexity of the Israeli state and its system of social stratification, which can be described as a society of separate enclaves. This system of separate ethno-religious groups has often been traced back to the 'millet system' of the Ottoman Empire when the various peoples of the Book enjoyed relative cultural and legal autonomy. This pattern of communal separation and juridical distinctiveness was continued under the British mandate when the various communities ran their own affairs within the spheres of the family, civil law and education. On the eve of Independence in 1947, the religious communities negotiated special exemptions (from military service) and special arrangements for religious education. As a result, the ultra-Orthodox parties have been able to dictate the membership of the Religious Councils, thereby controlling the administration of marriage, funerals, dietary regulations and so forth. Secular Jews who wish to marry outside the control of the rabbinate may have to travel to Cyprus to create a legal union. Control of education lies at the core of the enclave system in which ultraorthodox Jews (haredim) have successfully protected their children from exposure to 
the educational curriculum of secular Zionism. In this enclave society and its multiparty state, religious groups (of every shade of orthodoxy) compete for government funds to support the study of the Torah, to secure subsidised housing, to enjoy welfare and health benefits (Lehmann and Siebzehner 2006).

In contemporary Israel, the alienated Sephardic vote had been harvested initially by the right-wing Likud Party which challenged the Labour Party's earlier control over this Sephardic constituency. However, as Likud embraced neo-liberal policies the Sephardic electorate switched their vote to Shas, and as a result Shas gained six seats in 1992 and nine seats in the Knesset in 1996. In the late 1980s the Moroccanborn political leader of Shas Arieh Deri was accused of taking 'kickbacks' from government grants for a yeshiva (a centre for Torah learning). His conviction further fuelled the claim that Israel was a stratified society in which Sephardim were treated as racially inferior to the dominant group. With this resentment in the background, Shas won nineteen seats in the Knesset in 1999. Although their vote declined to eleven seats in 2003, Shas remains the fourth largest party, commanding control over the 'ethnic vote'. With seats in the government, Shas has been able to channel resources into its own communities as a reward for electoral support, thereby reinforcing the enclave structure of Israeli politics.

I have dwelt on this Israeli illustration because it has an important lesson for political theory. In her States and Social Revolutions in France, Russia and China Skocpol (1979) laid the foundation for a revival of political theory by showing in her research on revolutions that the state cannot be reduced to society, but acts instead as an autonomous historical force. The Israeli state perhaps proves the opposite statein-society theory that has been championed by Migdal (2001) in his State in Society. Migdal's argument is that states vary in effectiveness depending on their ties to society; states are not unitary actors but clusters of institutions and groups with conflicting interests; state policies reflect contingent pressures from their broader social context; and finally state and society can under some circumstances stand in a mutually corrosive relationship. Following Migdal a case could be made that Shas, along with other enclaves, actually damages the functions of the state. One lesson from the recent crisis in Lebanon may well be that Hizbollah rather than acting as a valuable element of civil society replaces the state, thereby reinforcing sectional interest. The general political lesson of any enclave society is that these enclaves preclude any effective policy response to ethnic stratification and do not create social capital. The management of religion in these circumstances becomes highly problematic, because the local practices of enclavement cannot be separated from their wider global significance.

\section{Strategies of religious management: group rights}

Because ethnic and religious conflicts in the modern world are exacerbated by globalisation, social philosophers have engaged in debates about how tolerance and cosmopolitanism might be promoted. These concerns have spawned a rich ensemble of theories and concepts - cosmopolitan virtue, care, tolerance, and recognition theory. Although these ideas are useful in the formulation of ethical orientations, they do not easily or immediately lead to empirical research strategies or to effective 
social policies. The work of Will Kymlicka has become important in addressing the issue of rights in ethnically diverse societies.

Kymlicka (1995) has defended the idea of group rights and cultural rights within a liberal framework (as a policy that has specific reference to multicultural societies like Canada and Australia). Kymlicka (1995:26) argues that liberal democracies that have accepted some form of multiculturalism typically make adjustments or accommodations to cultural pluralism through the mechanism of what he calls 'groupdifferentiated rights.' These are divided into three types. First, there are rights to self-government. In multinational states, the component nations may demand some level of political autonomy or territorial jurisdiction. The right of self-determination has been sanctioned by the United Nations' Charter - 'all peoples have a right to selfdetermination' - but the charter does not unfortunately define 'people.' In some societies, the demand for autonomy may result in secession, but one common institutional response to the demand for autonomy has been federalism. In some respects, Kymlicka's argument may therefore be specific to Canada, where federalism offers some solution to the demands of the Quebecois within a federal structure, or to Australia. The second accommodation is through the development of poly-ethnic rights. At a minimal level, these are merely rights to express cultural differences without exposure to prejudice. These rights are often expressed against so-called 'Anglo-conformity' which has involved the dominance of Anglo-American values in the public domain, relegating minority cultural practices to the private sphere. More radical demands for these rights may entail the exemption of ethnic groups from laws and regulations that are seen to disadvantage them. The point of these rights is to promote integration, whereas self government rights are to secure self government. Finally there are special representation rights in which minority or oppressed groups are given automatic or guaranteed representation in parliamentary and other democratic institutions. These rights can be regarded as a form of affirmative action, but they tend to be temporary. They are 'kick-start' devices to ensure an evolution towards adequate participation and they are subsequently abandoned once minority groups have entered the mainstream of the host community. These rights are aspects of the upgrading of cultural minorities.

The theory of differentiated rights, while providing a general legal framework, is in practice specific to Canadian history and society. As a federal and as a whitesettler society Canada has first-nation communities with a problematic relationship to Canadian history and sovereignty. In addition, it also has a substantial Frenchspeaking community in the state of Quebec. Some aspects of the argument however can apply to Europe, where federalism could be a useful principle of accommodation. In addition, poly-ethnic rights already apply to certain social groups, but not to others. The headscarf issue in French schools is the obvious illustration. However, one criticism of Kymlicka's general approach is the absence of any significant discussion of law. There is no attempt to connect legal pluralism with groupdifferentiated rights. Kymlicka's rights are in fact primarily cultural rights and hence the problem of legal sovereignty is not adequately addressed and yet the legal framework is a crucial ingredient of social harmony.

Kymlicka's contribution to liberal theory implies that societies can survive as effective democracies provided they are able to accommodate divergent cultures and identities. Other writers have been far more pessimistic about sustaining social order 
in the face of social diversity. This is because empirically cultural consensus in modern societies is rare: increasing social diversity undermines the cultural homogeneity of traditional societies. Co-operation with social norms affects attitudes towards how other people will co-operate, and in turn this expectation shapes assumptions about future behaviour. Social capital is a moral resource that increases with use (Putnam 2000). The growth of generalised trust is a function of everyday compliance with norms, and the more individuals cooperate with each other, the more they trust one another. Past experiences of reliable cooperative interaction tends to enhance our general sense of the trustworthiness of other people. In short, trustworthiness routinely generates trust, and conversely lack of reciprocity tends to deflate trust.

One consequence of cultural pluralism might therefore be legal pluralism. It legal pluralism is an inevitable consequence of multiculturalism, then Kymlicka's groupdifferentiated rights are underdeveloped because they do not recognise the importance of legal self determination. Legal pluralism would thus stretch the assumptions of liberalism to their limits. For example, the right to join or to leave a social group is central to liberalism. But in Islam there are traditional views that regard to the right to opt out as parallel to apostasy and they could not easily permit such arrangements. The notion that individuals can opt out of their own communities is perhaps the most problematic aspect of individual rights. In the case of minorities, the very survival of their cultures and traditions requires continuity of socialisation and transmission - a process that has historically depended on women. Hence, women are typically subject to excessive (and at times brutal) subordination to group norms.

\section{Managing religions: the enclave society}

Many of these liberal approaches assume the development of societies towards multiculturalism in which open borders and significant geographical mobility can be taken for granted. Having discussed the liberal model at some length, I shall conclude with a far more pessimistic vision of modern societies in terms of a theory of social enclaves. The problem of managing religion in modern society therefore becomes a problem of managing enclaves, and thereby to limit the contact between such enclaves. This pessimistic view of social change must start with a critique of the whole notion of modern mobilities.

Shamir (2005) has developed a powerful counter-vision to global mobility in his concept of a 'mobility regime', which describes the paradox that globalisation also produces new forms of social closure. There is a 'paradigm of suspicion' in which various categories of persons are seen to be dangerous, and hence their movements need to be contained and curtailed. Hence there is a need to conceptualise globalisation as also involving 'closure, entrapment and containment' (Shamir 2005:199). The result is an emerging system for the management and containment of risk that has a global reach. If we regard the right to be mobile as a resource, it is clear that the risks of insecurity are unequally shared by the population and hence there is a 'mobility gap' that is somewhat parallel to the 'information gap' and the 'digital divide.' Finally, Shamir detects an evolution of these systems from 'elementary forms' such as walls and fences to more complex systems involving for example the use of forensic 
medicine and bioprofiling. While Shamir's contribution to this debate is substantial, I have two minor comments on his approach. First, his idea of a 'mobility regime' should be re-titled as the 'immobility regime' and secondly the notion of biological closure can be usefully elaborated through a consideration of the work of Agamben (1998) on sovereignty and bare life.

We can initially distinguish two forms of enclavement. The first is what I shall call 'spontaneous enclavement.' This refers to the cultural practices of social groups that tend to produce social closure as a result for example of intra-cultural marriage. The second is what I shall call 'institutional enclavement.' This refers to the involuntary social closure of a social group with the specific aim of social exclusion. Furthermore, institutional enclavement can be either benign or malicious. Benign enclavement might include the use of quarantine to exclude individuals or social groups who are carriers of an infectious disease such as SARS. Such closures are likely to be short-term responses to environmental risks. Malevolent enclavement would include for example the use of concentration camps to control, demoralise or destroy a social group.

These closures can be considered in terms of their military-political, social and cultural or biological character. To describe these processes that seek to exercise governmentality, often in extreme form, over subordinate populations by enclosure, bureaucratic barriers, police surveillance, legal exclusions and registrations, we can employ the notion of enclavement as a set of tactics for domestic and international regulation. Rather than increasing mobility, we can see the emergence of an immobility regime of gated communities for the elderly, ghettoes for migrants, legal and illegal, imprisonment and a range of related practices (tagging) for criminals and deviants, and increasingly the need for quarantine to ensure biological containment against bird flu, TB, SARS, and HIV. At an everyday level, there are also many illustrations of such spatial closures. These are often benign : frequent-flyer lounges, prayer rooms and nosmoking areas in airports, or women-only carriages on Japanese railways. Many of these practices and institutions are ancient (such as the Great Wall of China and quarantine in plague-stricken medieval Europe), but with modern information technology, microbiological innovations and nanotechnology there are a range of new techniques available to states - in particular to control global flows and networks of slavery, crime, terrorism, and war lordism. The causes of the rise of enclave society are numerous globalisation of crime, 'the return of the state,' securitisation, illegal migration, political paranoia, and technical innovations.

While the creation of physical and bureaucratic fences to control migrants has been much discussed, the biological dimensions of enclavement are certainly the most interesting. Following the work of Agamben (1998) on 'bare life,' we can foresee a new apparatus of bio-sequestration, exclusion and regulation. However, Guantanamo Bay is probably the ultimate conversion of the city into the camp. These developments constitute a global process of enclavement resulting in an immobility not mobility regime.

Modern enclavement can assume three principal forms: sequestration, storage and seclusion. The isolation or sequestration of populations is the most basic form of social regulation with the aim of protecting host populations from disease or from dangerous persons. Such practices are essentially illustrations of what Max Weber referred to as social closure. By contrast, the creation of gated communities to protect the elderly or the vulnerable is designed, not to keep such threats on the outside, but to protect communities from dangers such as self harm. With the ageing 
of the populations of the developed world and increasing life expectancy, a range of strategies have emerged for the management of the elderly; these include the growth of overseas retirement villages, homes for the elderly and increasingly luxury cruise ships. Because it is unlikely that the deeply aged will ever return to the labour force, these strategies may be conceptualised as forms of 'social storage.' Finally there are a range of new laws and technologies which allow states to categorise and to track individuals who are deemed to be dangerous in order to bring about their spatial seclusion. The unemployable and the undesirable typically fall into a category of persons whose actions can come to be regarded as constituting 'offensive behaviour' (Turner 2006b). In the United Kingdom, the Anti-Social Behaviour Act has given extra-ordinary powers to the authorities to create zones from which persons deemed to be likely to cause an offence can be excluded. The Act also introduced penalties for beggars by making begging a notifiable offence. The Act creates provisions, not to solve or remove crimes, but to put them outside the gaze of virtuous citizens, thereby achieving an emotional seclusion.

On 13 August 1961 East German security forces sealed off most of the crossing points in Berlin, erecting barbed wire and concrete blocks to stop the flow of people and traffic. This wall was in reality to stop the exodus of East Germans to the West. Between 1949 and 1960 more than three and a half million had fled the GDR. Patrolling the Berlin Wall required some fourteen thousand guards and over six thousand dogs. The collapse of the Wall in 1989 coincided with the termination of the Soviet bloc as a whole. Like the historical use of quarantine, walls are a simple form of enclavement. The Berlin Wall was certainly a throwback to the Second World War and to the origins of the Cold War, but new walls are being constructed in Baghdad, the West Bank, Botswana, and Padua and along the Mexican-American border. For example, the left-wing city council of Padua has created a steel barrier to divide the respectable side of the city from the high crime neighbourhoods which are rife with illegal drugs associated with an influx of Nigerian and Tunisian migrants. In the Spanish enclave of Melilla in Morocco, the Guardia Civil fired shots at asylum seekers attempting to climb a six metre fence. In San Diego a wall also protects Californian citizens from immigrants crossing illegally from Tijuana (Paquot 2006). According to Prince Nayif, the Saudi Interior Minister, next year Saudi Arabia will build a security fence some $900 \mathrm{~km}$ long to secure the border, where the Saudis fear they will also suffer eventually from the political chaos in Baghdad. In the Iraqi capital, the American military has already built a 'green zone' with a ten mile long wall. In 2006 President George W. Bush signed the Secure Fence Act which anticipates the creation of a seven hundred mile barrier to deter illegal migrants.

Religious identities tend to be transnational, and offer alternative matrices of self definition that are not state based. There is as a result a tension between the transnational identities of neo-fundamentalist religions (Christian, Muslim, Jewish but also Hindu and Buddhist) and the state-based national identities of secular citizenship. In the American pattern of assimilation, Protestant, Catholic and Jew were alternative identities within a common pattern of civil religion. In Europe, however, there is no civil religion as such to which Muslim Europeans or Christian Europeans or Hindu Europeans could become culturally or emotionally attached. The idea of European common citizenship has been, at least for the time being, 
delayed by the rejection of the Constitution in the referenda in France and The Netherlands, and by the failure to agree on a common economic budget. This negative vote may also result in the termination of the process to bring Turkey into the European Union. Associated with this no vote there is a deep concern about the expansion of radical Islam into Europe, and the consequence of any delay in Turkish membership is to define Fortress Europe as primarily a Christian enclave (Delanty 2006). The political debate was started in Britain by Jack Straw, MP for Blackburn in Lancashire, who demanded that Muslim women should not wear the veil in public places on the grounds that it is thereby impossible to judge their emotions when their faces are obscured. This debate however reinforces the principle that Muslims (unlike Hindus or Buddhists) constitute a unique problem in civil society; they need to be managed, while Hindus can be neglected.

\section{Conclusion}

Since 9/11 diasporic Muslim communities around the world have been increasingly the target of government interventions, social surveys, politic investigations and popular criticism. The traditional indifference (or benign neglect) of governments has been replaced by sudden and intense activity. Because the idea of 'managing Muslims' would be regarded as discriminatory, these forms of governmentality are often couched in neutral terminology - pluralism, liberalism or multiculturalism. In this article I have examined the extreme poles of the new management of religions from liberal policies of upgrading (such as the allocation of resources for education and legislation for group rights) to more extreme policies of containment and seclusion which I have called policies of enclavement. A liberal policy of upgrading is benign by comparison with enclavement but it can also lead ultimately to winning 'the war for Muslim minds' (Kepel 2004). Enclavement will inevitably produce greater alienation of Muslim communities from their host societies, but management through seclusion appears to be the dominant pattern in association with a war on terrorism. The policy of upgrading can be successful, where it receives support from religious communities and their intellectuals who would prefer some level of secular modernisation over more traditional emphases on commitment to customary practices. In comparative global terms, the resources, status and performance of Muslim societies in education, especially in higher education, is poor, and hence a reformist strategy of improving the educational attainment of Muslims is highly desirable (Hassan 2006).

What is to be done? Positive state policies towards minorities cannot succeed unless there are parallel social changes in civil society that create new patterns of social solidarity that are strong enough to cross enclaves. A successful society that is diverse and complex needs a strong legal framework and effective citizenship to create a public environment in which overt and blatant racism is not tolerated and where assumptions about cultural diversity are core elements of government business. Governments need such explicit policies that convey to the public the principle that the government does not favour one ethnic or religious group over another, and hence minority rights are clearly protected by the law. Secondly there must be sufficient economic growth and an adequate welfare and taxation system to 
redistribute resources in such a way that second-generation children of migrant families are not systematically disadvantaged. Therefore, educational policies and resources are therefore fundamental to success. Thirdly, there must be a social climate that allows for inter-marriage, social reciprocity and the emergence of intermediate associations (clubs, churches and voluntary associations) to build up social capital as the foundation of liberal values. These overlapping social groups are the social supports that make possible an overlapping consensus of value and belief. Finally, there must be cultural sphere (including sport and other leisure activities) where general values (Rawls's overlapping consensus) can counteract the tendency towards group loyalty, localism, tribalism or ethnic solidarity. Without these overlapping social groups, any liberal hope of fostering an overlapping consensus is doomed to failure, and enclavement will ensue.

\section{References}

Agamben, G. (1998). Homo sacer. Sovereign power and bare life. Stanford: Stanford University Press.

Boltanski, L., \& Chiapello, E. (2005). The new spirit of capitalism. London: Verso.

Delanty, G. (2006) Borders in a changing Europe: Dynamics of openness and closure. Comparative European Politics, 4, 183-202.

Foucault, M. (2000). Governmentality in power. The essential works 3 (pp. 201-222). London: Allen Lane. Hassan, R. (2006). Nations locked in servitude by a gulf in learning. The Times Higher Education Supplement, 2 November.

Huntington, S. P. (1993). The clash of civilizations. Foreign Affairs, 72(3), 22-48.

Kepel, G. (2004). The war for Muslim minds. Islam and the west. Cambridge, MA: Belknap.

Kymlicka, W. (1995) Multicultural citizenship. A liberal theory of minority rights. Oxford: Oxford University Press.

Lehmann, D., \& Siebzehner, B. (2006). Remaking Israeli Judaism. The challenge of Shas. London: Hurst Company.

Locke, J. (1946) The second treatise of government. Oxford: Basil Blackwell.

Migdal, J. (2001) State in society. Studying how states and societies transform and constitute one another, New York: Cambridge University Press.

Paquot, T. (2006). Through the gate and over the wall. Le Monde Diplomatique, 14-15, 14 October.

Putnam, R. D. (2000). Bowling alone. The collapse and revival of American community. New York: Simon \& Schuster.

Rawls, J. (1999). The law of peoples. Cambridge, MA: Harvard University Press.

Sadri, M., \& Sadri, A. (Eds.) (2000) Reason, freedom and democracy in Islam.The essential writings of Abdolkarim Soroush. Oxford: Oxford University Press.

Shamir, R. (2005). Without borders? Notes on globalization as a mobility regime. Sociological Theory, 23 (2), 197-217.

Skocpol, T. (1979) States and Social Revolutions in France, Russia and China. Cambridge: University of Cambridge Press.

Turner, B. S. (2006a). Citizenship and the crisis of multiculturalism. Citizenship Studies, 10(5), 607-618.

Turner, B. S. (2006b). Social capital, trust and offensive behaviour. In A. V. Hirsch \& A. P. Semester (Eds.), Incivilities: Regulating offensive behaviour (pp. 219-238). Oxford and Portland, OR: Hart. 